\title{
THEORITICAL REVIEW: PEMASARAN MEDIA SOSIAL
}

\author{
Oleh : \\ Rina Sari Qurniawati \\ Dosen Tetap STIE AMA Salatiga
}

\begin{abstract}
The emerging of social media technology and the popularity of social media sites stem from a simple fact that human beings are social by nature. People are inclined to collect or share information that is important to them. Social media has become one of the most popular marketing channels for many companies, which aims at maximizing their influence by various marketing campaigns conducted from their social accounts on social networks. Social networking sites have become an avenue where retailers can extend their marketing campaigns to a wider range of consumers. Nowadays, it is practically impossible to formulate marketing strategy without taking social networks into consideration. Adapting some forms of marketing online through social media is a key node for all businesses. The importance of social media lies in its function as the new marketing/promotion platform, which may timely and interactively connect seller and buyers. Business-to consumer or business-to-business reasons use social media in every aspect of their daily life.
\end{abstract}

Keywords: Social Media, Marketing, IMC, marketing tools

\section{PENDAHULUAN}

Perkembangan web 2.0 merubah pandangan semua orang tentang bagaimana cara berkomunikasi, bekerja sama dan menyebarkan informasi. Semakin banyaknya media sosial yang muncul akhir -akhir ini misalnya Facebook, Instagram, Whatsapp, dan twitter membuat para penggunanya lebih banyak menghabiskan waktu untuk berkomunikasi secara online daripada bertemu langsung. Media sosial dikenal juga sebagai 'komunikasi yang dihasilkan pengguna', sekarang mewakili sumber informasi yang lazim; telah mengubah alat dan strategi yang digunakan perusahaan untuk berkomunikasi, menyoroti bahwa kontrol informasi sekarang berada di tangan pelanggan (Mangold \& Faulds 2009). Pada tahun 2011, lebih dari 50\% pengguna media sosial mengikuti akun sebuah merek di media sosial (Van Belleghem, Eenhuizen, dan Veris 2011) dan perusahaan semakin berinvestasi di media sosial, yang ditunjukkan oleh belanja pemasaran di seluruh dunia pada situs jejaring sosial sebesar \$ 4,3 miliar (Williamson 2011). 
Pemasaran sendiri merupakan sebuah ilmu yang berkembang dengan baik dan secara konstan mengubah aturannya sesuai dengan kebutuhan dan perkembangan yang terjadi di dalam dan di sekitarnya. Peran pemasaran dalam pengembangan bisnis berubah secara radikal sejak komunikasi dengan internet berkembang secara luas terutama dengan munculnya sosial media. Teknologi web membuat dan mengunggah konten mereka sendiri melalui sosial media. Konten yang mereka unggah dapat dilihat oleh jutaan orang dengan gratis dan pengiklan tidak perlu membayar uang dalam jumlah besar ketika mereka akan menyematkan iklan mereka di media sosial (Saravanakumar dan Lakshmi, 2012). Perusahaan kini telah menembus jejaring sosial online dengan menawarkan tautan langsung dari situs web perusahaan mereka ke Facebook dan Twitter, dan menggunakan alat ini untuk mempromosikan merek dan mendukung pembentukan komunitas merek mereka (Kaplan \& Haenlein 2010).

Media sosial kini menjadi sebuah fenomena yang berkembang dalam dunia pemasaran. Pemasar mulai memahami penggunaan media sosial sebagai komponen dalam strategi pemasaran mereka. Media sosial, yang mencakup saluran online untuk berbagi dan berpartisipasi dalam berbagai kegiatan, merupakan cara yang semakin penting bagi merek untuk berkomunikasi secara interaktif dengan konsumennya (Murdough, 2009). Dalam waktu yang relatif singkat, para pemasar telah menjadikan pemasaran media sosial untuk berbagai tujuan pemasaran termasuk branding, penelitian, manajemen hubungan pelanggan, layanan, dan promosi penjualan dimana media sosial dinilai paling untuk pencitraan merek (eMarketer, 2013). Menurut Laporan Industri Media Sosial 2013 (Stelzner, 2013), 86\% pemasar percaya saluran media sosial adalah komponen penting untuk pemasaran mereka.

Pemasaran media sosial dapat dengan mudah didefinisikan sebagai penggunaan saluran media sosial untuk mempromosikan perusahaan dan produknya. Jenis pemasaran ini dapat dianggap sebagai bagian dari aktivitas pemasaran online yang melengkapi strategi promosi berbasis Web tradisional, seperti buletin email dan kampanye iklan online (Barefoot dan Szabo, 2010). Media sosial, dengan cara tertentu, mengubah konsumen menjadi pemasar dan pengiklan, dan konsumen dapat menciptakan tekanan positif atau negatif bagi perusahaan, produknya, dan layanannya, tergantung pada bagaimana perusahaan disajikan secara online dan pada kualitas produk dan layanan disajikan kepada pelanggan (Roberts dan Kraynak 2008, 146). 
Pemasaran media sosial berbeda dari metode pemasaran tradisional, oleh karena itu diperlukan perhatian khusus dan pembentukan strategi untuk mencapai citra merek dan kesetiaan. Pemasaran media sosial terkait dengan pemasaran hubungan, di mana perusahaan perlu beralih dari "mencoba menjual" ke "membuat hubungan" dengan konsumen (Gordhamer, 2009). Pemasaran sosial media juga dilihat lebih tulus karena dalam berkomunikasi dengan konsumennya, pemasar mencoba menunjukkan tentang merek tersebut dibandingkan dengan mencoba untuk mengendalikan citra merek. Menjadi merek yang selalu kompetitif dalam bisnis yang bergerak cepat saat ini membutuhkan strategi media sosial yang solid. Perusahaan mempekerjakan ahli dan konsultan media sosial untuk memutuskan konten dan karakteristik dari penawaran dan kegiatan mereka di lingkungan media sosial sehingga hati dan pikiran konsumen ditangkap dan loyalitas merek mengikuti (Coon, 2010).

\section{PEMASARAN MEDIA SOSIAL DAN FITUR-FITURNYA}

Pemasaran dengan media sosial membuat dampak yang signifikan terhadap strategi pemasaran sebuah perusahaan. Pemasaran semacam ini secara bertahap meningkat, berkembang, dan menggantikan metode yang lebih tua di beberapa perusahaan. Misalnya, aplikasi pemasaran tradisional, seperti pemasaran langsung dan pemasaran merek, adalah teknik satu arah, berbasis push dan interrupt-driven. Jenis kegiatan pemasaran ini diarahkan dari perusahaan ke pelanggan. Tanpa permintaan dari pelanggan potensial, perusahaan " mendorong " aktivitas pemasaran ke klien, dan ini dapat dicapai dengan mengganggu aktivitas mereka. Menurut Awareness (2008), pemasaran media sosial terdiri dari fitur-fitur baru, seperti berikut:

1. Pemasaran media sosial terdiri dari dialog multi arah. Merek berbicara dengan pelanggan, pelanggan berbicara dengan merek, dan — mungkin yang paling penting - pelanggan berbicara satu sama lain. Situasi ini adalah jenis ikatan baru yang tidak mungkin dilakukan sebelum munculnya Web 2.0.

2. Pemasaran media sosial bersifat partisipatif. Apa yang membuatnya sosial adalah bahwa itu tergantung pada partisipasi pengguna. Agar pemasaran media sosial dapat direalisasikan, partisipasi pengguna diperlukan.

3. Pemasaran media sosial dihasilkan oleh pengguna. Sebagian besar konten dan koneksi dalam komunitas online dibuat oleh pengguna, bukan oleh merek. Tidak diragukan lagi, beberapa konten dan percakapan dihasilkan oleh merek, 
tetapi jenis konten dan percakapan ini sedikit. Tujuannya adalah untuk membuat pengguna berbicara.

Dengan munculnya media sosial yang berbasis internet, sangat dimungkinkan seseorang berbagi pendapat tentang sebuah produk atau perusahaan dengan ribuan orang dalam waktu yang singkat. Dengan cara ini, pengaruh komunikasi dari konsumen ke konsumen sangat melebar di pasar (Mangold and Faulds 2009, 357). Semua jenis media sosial memberikan kesempatan mempresentasikan sebuah merek kepada komunitas yang dinamis dan individu yang mungkin tertarik (Roberts dan Kraynak 2008, 149). Media sosial mencakup berbagai aplikasi yang, menggunakan istilah teknis, memungkinkan konsumen untuk " memposting, " " tag", " blog, " dll. Konten ini dibuat oleh media sosial adalah jenis sumber daya yang baru dibuat untuk informasi online yang dibuat, disebarkan, dan digunakan oleh konsumen yang menginginkannya

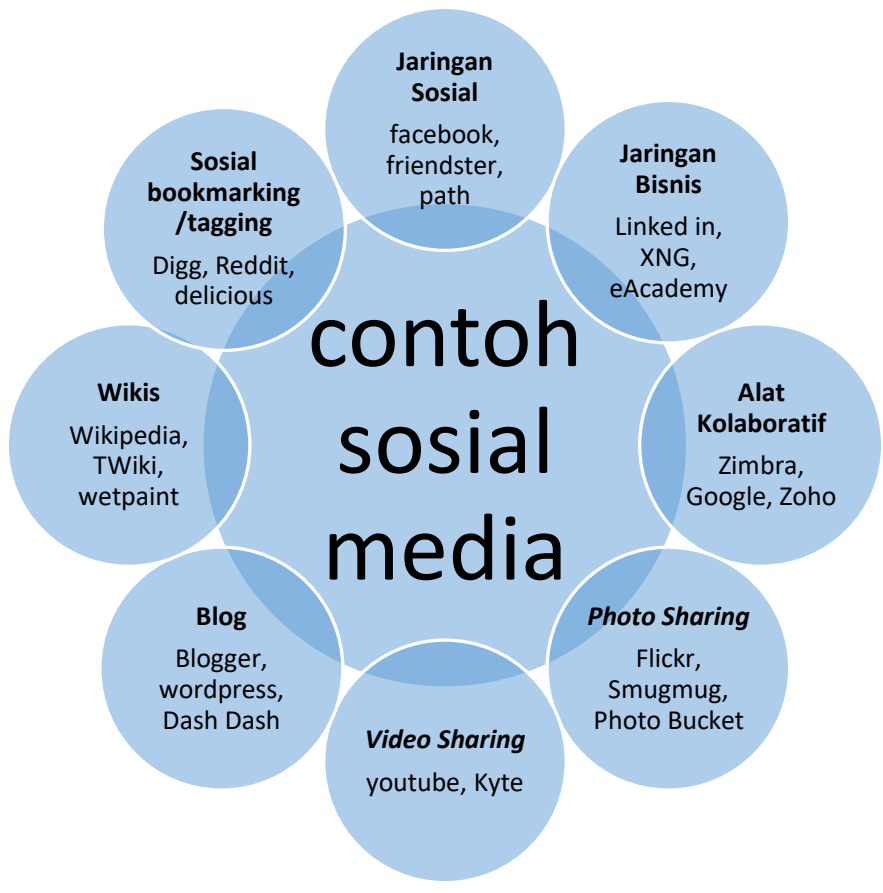

Gambar 1

Contoh dari Tipe Sosial Media

Konsumen menerima informasi tentang produk dan layanan dari sumber informasi alternatif, terutama dengan berkonsultasi dengan konsumen lain melalui komentar online dan situs web jejaring sosial elektronik (Clemons 2009, 48). Ketika 
tiba waktunya bagi konsumen untuk membeli produk atau layanan, mereka mencari pendapat orang lain lagi (Akar 2010a, 115). Menurut sebuah penelitian oleh Nielsen BuzzMetrics, lebih dari 60 persen konsumen percaya apa yang mereka baca di pospos konsumen lain (Blackshaw dan Nazzaro 2006, 5). Menurut Red Bridge Marketing (2008), mengenai produk dan layanan, 78 persen konsumen global percaya dan mempercayai saran orang lain atas data lainnya.

Media sosial memiliki aspek interpersonal, sehingga pengaruh normatif dan informasi dapat bekerja untuk, atau melawan, merek, tergantung pada keterlibatan konsumen (Mangold \& Faulds, 2009). Konsumen secara strategis memilih merek yang akan mereka diskusikan dalam komunikasi online untuk membangun citra diri yang positif (Schau \& Gilly, 2003). Pemasar merek peduli tentang pilihan merek ini karena teori identitas menunjukkan bahwa komitmen merek menghubungkan individu ke pada lini kegiatan yang konsisten seperti perilaku pembelian (Burke \& Reitzes, 1991).

\section{KOMUNIKASI PEMASARAN TERPADU (INTEGRATED MARKETING COMMUNICATIONS)}

Komunikasi pemasaran terpadu secara tradisional dianggap sebagai komunikasi satu arah. Dalam paradigma lama, organisasi dan agennya mengembangkan pesan dan mengirimkannya ke konsumen potensial, yang mungkin atau mungkin tidak bersedia berpartisipasi dalam proses komunikasi. Kontrol atas penyebaran informasi ada di tangan organisasi pemasaran perusahaan. Unsur-unsur tradisional dari bauran promosi (iklan, penjualan pribadi, hubungan masyarakat dan publisitas, pemasaran langsung dan promosi penjualan) merupakan hal yang dikendalikan.

Di abad ke dua puluh satu ini kita menyaksikan ledakan pesan berbasis Internet yang ditransmisikan melalui media-media ini. Mereka telah menjadi faktor utama dalam mempengaruhi berbagai aspek perilaku konsumen termasuk kesadaran, perolehan informasi, pendapat, sikap, perilaku pembelian dan komunikasi dan evaluasi pasca-pembelian. Sayangnya, pers bisnis populer dan literatur akademis menawarkan sangat sedikit panduan bagi manajer pemasaran untuk memasukkan media sosial ke dalam strategi komunikasi pemasaran terpadu mereka. Menurut 
Hollensen, Jejaring sosial sebagai alat komunikasi memiliki dua peran promosi yang saling terkait, yaitu:

1. Jejaring sosial harus konsisten dengan penggunaan alat Komunikasi pemasaran terpadu tradisional. Artinya, perusahaan harus menggunakan media sosial untuk berbicara dengan pelanggan mereka melalui platform seperti blog, serta grup Facebook dan Twitter. Media ini dapat disponsori perusahaan atau disponsori oleh individu atau organisasi lain.

2. Jejaring sosial memungkinkan pelanggan untuk berbicara satu sama lain. Ini adalah perpanjangan dari komunikasi word-of-mouth tradisional. Sementara perusahaan tidak dapat secara langsung mengendalikan pesan konsumen-ke konsumen (C2C), mereka memiliki kemampuan untuk mempengaruhi percakapan yang dimiliki konsumen dengan satu sama lain. Namun, kemampuan konsumen untuk berkomunikasi dengan satu sama lain dibatasi.

Manajer pemasaran mencari cara untuk memasukkan media sosial ke dalam strategi Komunikasi pemasaran terpadu mereka. Paradigma komunikasi tradisional, yang bergantung pada bauran promosi klasik untuk menciptakan strategi komunikasi pemasaran terpadu, harus memberi jalan kepada paradigma baru yang mencakup semua bentuk media sosial sebagai alat potensial dalam merancang dan menerapkan strategi komunikasi pemasaran terpadu. Pemasar kontemporer tidak dapat mengabaikan fenomena media sosial, di mana informasi pasar yang tersedia didasarkan pada pengalaman konsumen individual dan disalurkan melalui bauran promosi tradisional. Namun, berbagai platform media sosial, banyak yang benar-benar independen dari organisasi penghasil / sponsor atau agennya,sehingga meningkatkan kemampuan konsumen untuk berkomunikasi satu sama lain.

Tabel 1

Jenis Gaya Komunikasi

\begin{tabular}{|l|l|}
\hline \multicolumn{1}{|c|}{ Gaya Komunikasi } & \multicolumn{1}{c|}{ Keterangan } \\
\hline Periklanan Tradisional Satu Arah (The & Contohnya:iklan media massa seperti \\
Traditional one-way advertising) & iklan televisi, surat kabar / iklan majalah, \\
& dll. mewakili pendekatan "Bowling" di \\
& mana perusahaan berusaha "memukul" \\
& banyak pelanggan dengan metode media \\
\hline
\end{tabular}




\begin{tabular}{|c|c|}
\hline & $\begin{array}{l}\text { massa "senapan". Biasanya pendekatan } \\
\text { ini adalah jenis komunikasi satu arah. }\end{array}$ \\
\hline $\begin{array}{l}\text { Interaksi yang digerakkan oleh pelanggan } \\
\text { (Customer-driven interaction) }\end{array}$ & $\begin{array}{l}\text { Mewakili tingkat interaksi yang lebih } \\
\text { tinggi antara perusahaan dan pelanggan } \\
\text { utamanya yang berbeda. Seringkali } \\
\text { perusahaan menemukan beberapa akun } \\
\text { manajer kunci, yang memiliki tanggung } \\
\text { jawab untuk menjaga interaksi satu-ke- } \\
\text { satu antara perusahaan dan akun-akun } \\
\text { utamanya (pelanggan). }\end{array}$ \\
\hline Pemasaran Viral (Viral Marketing) & $\begin{array}{l}\text { Mewakili versi 1.0 Pemasaran Media } \\
\text { Sosial, di mana perusahaan misalnya } \\
\text { menggunakan video YouTube yang tidak } \\
\text { tradisional untuk mendapatkan perhatian } \\
\text { dan kesadaran tentang mereknya. } \\
\text { Interaksi antara 'pelanggan' potensial } \\
\text { cukup tinggi (situs blogging dll.), Tetapi } \\
\text { umpan balik ke perusahaan relatif rendah } \\
\text { (tidak ada panah ganda kembali ke } \\
\text { perusahaan). }\end{array}$ \\
\hline $\begin{array}{l}\text { Pemasaran Sosial Media (Social Media } \\
\text { Marketing) }\end{array}$ & $\begin{array}{l}\text { mewakili versi } 2.0 \text { dari Pemasaran Media } \\
\text { Sosial, di mana ada juga umpan balik } \\
\text { yang luas kepada perusahaan itu sendiri } \\
\text { (panah ganda kembali ke perusahaan). Di } \\
\text { sini perusahaan secara proaktif telah } \\
\text { memilih untuk menjadi co-player dalam } \\
\text { diskusi di berbagai situs media sosial } \\
\text { yang relevan (Facebook, Twitter, dll.). Ini } \\
\text { juga berarti bahwa perusahaan di sini } \\
\text { mencoba memperkuat interaksi dengan } \\
\text { pelanggan dalam arah yang positif, untuk } \\
\text { mempengaruhi perilaku pelanggan. Untuk }\end{array}$ \\
\hline
\end{tabular}




\begin{tabular}{|l|l|}
\hline & $\begin{array}{l}\text { melakukannya, perusahaan memerlukan } \\
\text { tim back-up karyawan media sosial yang } \\
\text { dapat berinteraksi dan berkomunikasi } \\
\text { secara online dengan pelanggan potensial } \\
\text { dan aktual. Akibatnya, strategi ini juga } \\
\text { sangat menuntut sumber daya. }\end{array}$ \\
\hline
\end{tabular}

\section{SOSIAL MEDIA SEBAGAI ALAT PEMASARAN}

Alat dan pendekatan untuk berkomunikasi dengan pelanggan telah sangat berubah dengan munculnya media sosial; oleh karena itu, bisnis harus belajar bagaimana menggunakan media sosial dengan cara yang konsisten dengan rencana bisnis mereka (Mangold and Faulds, 2009). Hill, Provost, dan Volinsky (2006) menyatakan bahwa perusahaan dapat memperoleh manfaat dari jejaring sosial untuk memprediksi kemungkinan niat membeli. Ini dapat dilakukan dengan mempertimbangkan pilihan jaringan perusahaan (yaitu Facebook, Instagram, Pinterest, dll.) dan dengan memeriksa data jaringan tersebut. Menilai data jaringan secara substansial meningkatkan upaya pemasaran perusahaan karena menyediakan perusahaan dengan informasi penting pada pengguna jaringan, yang membantu menentukan taktik media sosial terbaik untuk situs tertentu (Hill, Provost, dan Volinsky, 2006). Berdasarkan penelitian ini, selanjutnya dapat dikatakan bahwa mengetahui situs media sosial mana yang digunakan oleh pasar target perusahaan merupakan faktor kunci lain dalam menjamin bahwa pemasaran online akan berhasil.

Sorescue dkk. (2011), menekankan bahwa pengecer harus melampaui aspek periklanan situs jejaring sosial dan menemukan cara-cara inovatif untuk menggunakannya sebagai cara untuk melakukan percakapan dengan konsumen, bukan jaringan komunikasi satu arah. Sinclair dan Vogus (2011) menetapkan bahwa perusahaan besar harus melihat situs media sosial sebagai alat strategis dan beberapa bisnis bahkan mempekerjakan karyawan untuk mengawasi halaman media sosial mereka. Konsumen tidak lagi menjadi penerima pesan pemasaran yang pasif, sebaliknya mereka menggunakan Facebook, MySpace, YouTube, dan Twitter untuk menyuarakan pendapat mereka - baik positif maupun negatif "(Sinclair dan Vogus 2011, 293). Partisipasi konsumen dengan merek di media sosial memperkuat 
kebutuhan bagi pengecer untuk menjadi peserta aktif di situs jejaring sosial dan komunitas merek virtual yang mereka buat.

Situs jejaring sosial digunakan untuk meningkatkan daya tarik merek perusahaan dan meningkatkan target pasar mereka karena teknologi baru memungkinkan untuk komunikasi yang lebih pribadi serta dapat meningkatkan partisipasi konsumen dalam penciptaan pemasaran dan informasi terkait merek (Cappo 2033; Jaffe 2005 sebagaimana dikutip di Muñiz dan Jensen Schau 2007, 35). Mangold and Faulds (2009) menekankan bahwa contoh komunikasi tradisional, yang bergantung pada bauran promosi klasik untuk menciptakan komunikasi pemasaran terpadu, harus memberi jalan kepada paradigma baru yang mencakup semua bentuk media sosial sebagai alat potensial dalam merancang dan menerapkan strategi komunikasi pemasaran terpadu. Umpan balik dari konsumen selalu penting ketika datang ke produk, merek, dan pengembangan model bisnis. Hal ini karena pemasaran media sosial dapat digabungkan dalam rencana bisnis, dan meilhat bagaimana mengukur tanggapan konsumen.

Sudah jelas bahwa ketika para pemasar dari perusahaan besar menghadirkan produk atau merek baru, mereka menggunakan media tradisional maupun non tradisional untuk menempatkan iklan untuk memastikan mereka mencapai target pasar mereka (Cheong dan Morrison 2008). Pengecer kecil juga harus mulai menggunakan metode pemasaran non-tradisional dengan cara yang kreatif dan menarik untuk memastikan bahwa mereka menarik lebih banyak konsumen. Sorescu dkk. $(2011,11)$ menyatakan bahwa cara lain di mana pengecer dapat melibatkan pelanggan adalah dengan menjual bukan hanya produk saja,akan tetapi seluruh pengalaman menarik yang ditimbulkan dari sebuah produk.

\section{DAFTAR PUSTAKA}

Awareness. 2008b. Social media marketing: Integrating social media in your marketing mix.: http://www.awarenessnetworks.com/resources/IntegratingSocialMedia.pdf (accessed July 24, 2018).

Barefoot, D., and J. Szabo. 2010. Friends with benefits: A social media marketing handbook. San Francisco: No Starch Press. 
Blackshaw, P., and M. Nazzaro. 2006. Consumer-generated media (CGM) 101 wordof-mouth in the age of the Web-fortified consumer. 2nd ed. New York: BuzzMetrics, Inc

Clemons, E. K. 2009. The complex problem of monetizing virtual electronic social networks. Decision Support Systems 48:46-56. Communications." Journal of Advertising 36: 35-50.

Coon, M. (2010). Social Media Marketing: Successful Case Studies of Businesses Using Facebook and YouTube with an In-Depth Look into the Business Use of Twitter. M.A. Thesis. Stanford University, Stanford, CA.

Hill, Shawndra, Foster Provost, and Chirs Volinsky. 2006. "Network Based Marketing: Identifying Likely Adaptors via Consumer Networks." Statistical Science 21: 256-276.

Kaplan, A. M., \& Haenlein, M. (2010). Users of the world, unite! The challenges and opportunities of social media. Business Horizons, 53 (1), 59-68. Management 12: 293-314, DOI 10.1007/s10799-011-0086-5.

Mangold, W. G. \& Faulds, D. J. (2009). Social media: The new hybrid element of the promotion mix.Business Horizons, 52, 357-365.

Muñiz, Jr, Albert \& Schau, Hope. (2007). Vigilante Marketing and Consumer-Created Communications. Journal of Advertising. 36. 35-50. 10.2753/JOA00913367360303 .

Murdough, C. (2009). Social media measurement: It's not impossible. Journal of Interactive Advertising, 10, 94-99.

Roberts, R. R., and J. Kraynak. 2008. Walk like a giant, sell like a madman. Hoboken, NJ: Wiley.

Saravanakumar, M. \& Lakshmi, T.S. (2012). Social Media Marketing. Life Science Journal,9(4)

Schau, H., \& Gilly, M. (2003). We are what we post? Selfpresentation in personal web space. Journal of Consumer Research, 30, 385-404.

Sinclaire, Jollean K. and Clinton E. Vogus. 2011. "Adoption of social networking sites: an exploratory adaptive structuration perspective for global organizations." Information Technology

Sorescu, Alina, Ruud T. Frambach, Jagdip Singh, Rangaswamy Arvind, and Cheryl Bridges. 2011. "Innovations in Retail Business Models." Journal of Retailing 1: s3-s16.

Van Belleghem, Steven, Marloes Eenhuizen, and Elias Veris (2011), Social Media Around the World 2011. InSites Consulting. Retrieved 18-06-2018 from 
[http://www.slideshare.net/stevenvanbelleghem/social-media-aroundtheworld-2011/download? lead=394fd930572c9b62fb082021af5a6d0922046ec4].

Williamson, Debra A. (2011), "Worldwide Social Network Ad Spending: A Rising Tide", eMarketer.com. Retrieved 18-06-2018 from [http://www. emarketer.com/Report.aspx?code=emarketer_2000692]. 